\title{
Manevi İyilik Hali Envanteri'ni Türkçeye Uyarlama Çalışması
}

\author{
VELİ DUYAN \\ Ankara Üniversitesi Sağllk Bilimleri Fakültesi \\ vduyan@health.ankara.edu.tr \\ D https://orcid.org/0000-0003-4316-5756 \\ CENGIZ KILIC \\ Atatürk Üniversitesi Açık Öğretim Fakültesi \\ cengiz.kilic@atauni.edu.tr \\ https://orcid.org/0000-0003-1640-0132 \\ MERVE DENIZ PAK GÜRE \\ Başkent Üniversitesi Sağlık Bilimleri Fakültesi \\ mervedenizpak@gmail.com \\ https://orcid.org/0000-0001-7060-3729
}

\begin{abstract}
Öz
Manevi iyilik hali, bireyin manevi olarak önem verdiği ilahi değerlerin, toplum ve kendisi ile tutarlı ve dengeli bir bütünleşme içerisinde olması anlamında kullanılan bir kavramdır. Manevi iyilik hali dinî bilimler, psikoloji, felsefe ve sosyal hizmet gibi pek çok disiplin tarafından ilgi duyulan ve çalıșmalar gerçekleștirilen bir alandır. Manevi iyilik halinin değerlendirilmesine ilişkin gerek nitel gerekse nicel ölçme ve değerlendirme araçlarına gereksinim duyulmaktadır. Bu çalıșmada manevi iyiliği çok boyutlu olarak değerlendirmeyi sağlayan ve Ingersoll tarafından 1995 yılında geliștirilen Manevi İyilik Hali Envanteri'nin (MİHE) Türkçe sürümünün geçerlik ve güvenirlik düzeyinin belirlenmesi amaçlanmıștır. Calıșma, üniversite öğrencisi olan ve \%64'ü kadınlardan oluşan 513 kişi ile gerçekleştirilmiştir. MİHE'nin orijinal yapısının doğrulanıp doğrulanmadığının belirlenmesi amacıyla çalışma grubundan elde edilen verilere doğrulayıcı faktör analizi yapılmıștır. Doğrulayıcı faktör analizi sonucunda ki-kare ve serbestlik derecesi değerlerinde 3907,17 ve sd=2,84 oranı elde edilmiştir. Bu kapsamda belirlenen model ile veri arasındaki uyum, mükemmel uyuma karşılık gelmektedir. Sonuç olarak manevi iyilik halini ölçmek amacıyla geliştirilen MïHE'nin Türkçe sürümünün maddelerinin istenen özelliklere sahip olduğu, güvenirliğinin ve geçerliğinin yüksek bulunduğu belirlenmiștir.
\end{abstract}

Anahtar Kelimeler: Maneviyat, Manevi İyilik Hali, Geçerlik ve Güvenirlik, Envanter, Ölçek Uyarlama. 


\section{The Turkish Adaptation of the Spiritual Wellness Inventory Abstract}

Spiritual wellness is defined as the individual's consistent and balanced integration with divine values, society, and himself/herself. Spiritual wellness is an area of interest and studies carried out by many disciplines like religious sciences, psychology, philosophy, and social work. There is a need for both qualitative and quantitative measurement and evaluation tools to evaluate spiritual wellness. This study aims to determine the validity and reliability level of the Turkish version of the Spiritual Wellness Inventory developed by Ingersoll (1995), which allows evaluating spiritual wellness multidimensionally. The sample of the study consisted of 513 university students that $64 \%$ of whom were females. To determine whether the original structure of the Spiritual Wellness Inventory was confirmed, confirmatory factor analysis was applied to the data obtained from the study group. As a result of confirmatory factor analysis, chi-square and degrees of freedom values were 3907,17 and $s d=2,84$. The fit between the model determined in this context, and the data corresponds to an excellent fit. As a result, it was determined that the Turkish version of the Spiritual Wellness Inventory items had the desired properties, and its reliability and validity were high.

Keywords: Spirituality, Spiritual Wellness, Validity and Reliability, Inventory, Scale Adaptation.

\section{Giriş}

Maneviyat (spiritüellik) kavramının tanımlanması oldukça güçtür. Maneviyatın sözlük anlamına bakıldığında ruhanilik, tinsellik ve dinsellik gibi kavramlar ile karşılaşılmakla birlikte kavramın "maddi veya fiziksel şeylerin aksine insan ruhu ile ilgili olma niteliği" olarak tanımlandığı görülmektedir. ${ }^{1} \mathrm{Bu}$ kavram çerçevesinde yapılan diğer tanımlara bakıldığında "insanların yașamak istediği en derin değerlere ve anlamlara" işaret ettiğini söylemek mümkündür. ${ }^{2}$ Başka bir deyişle maneviyat, "insan ruhuna ve onun tam potansiyeline ulaşmasına neyin yardımcı olacağına dair bir tür vizyon" anlamına gelmektedir. ${ }^{3} \mathrm{Bu}$ yönü ile maneviyat, kişinin yaşama arzusu ve hayata bağlı olma süreci gibi içsel kaynakların bütünü olarak tanımlanmaktadır. Maneviyat literatürde "kişilerin kendisi ve diğer insanlarla ilişkilerini ve kişinin evrendeki yerini anlamaya çalışma ve kabul etme gayreti ile kendilerini ifade etmeleri için geniş bir yelpazede kullanılan kişisel anlamlar, ilişkiler ve yorumları içeren" bir çatı kavram olarak

\footnotetext{
1 Oxford Dictionary, "Definition of Spirituality," https://www.lexico.com/definition/spirituality (28.06.2021)

2 Philip Sheldrake, A Brief History of Spirituality (London: John Wiley \& Son, 2009), s.1.

${ }^{3}$ Hediye Arslan ve Dilek Konuk Şener, "Stigma, Spiritüalite ve Konfor Kavramlarının Meleis'in Kavram Geliștirme Sürecine Göre İrdelenmesi," Maltepe Üniversitesi Hemşirelik Bilim ve Sanatı Dergisi 2:1 (2009), ss.51-58.
} 
anılmaktadır. ${ }^{4}$ Bu bilgiler ışığında maneviyat, bireyin; yaşamındaki anlam, amaç ve yön arayışı ile ilişkili olarak benliğin ötesinde bir şeye olan inancı olarak ifade edilebilir.

Maneviyat farklı boyutları ile geçmişten günümüze pek çok disiplin tarafından ele alınan bir konu olmuştur. Bilimsel düşüncenin ön plana çıktığı Aydınlanma Döneminde özellikle Sigmund Freud ve Albert Ellis gibi psikoloji alanında önde gelen isimler din ve maneviyatın psikoterapiye dahil edilmesi konusunda olumsuz görüşlere sahip olmuşlardır. ${ }^{5} \mathrm{Bu}$ görüşlere karşıllk Abraham Maslow, Carl Jung ve Gordon Allport ise maneviyatın psikolojik iyi olma haline entegrasyonunu önemli görmüşlerdir. 6 1990'lara kadar devam eden bu görüş ayrılıkları terapötik süreçlerde kültürel yeterlilik, çeşitlilik ve duyarlılık alanlarının ön plana çıkmasıyla beraber maneviyatın genellikle insanları terapiye getiren çeşitli konularla iç içe olduğunun farkına varılmasını sağlamıștır. ${ }^{7}$ İlerleyen yıllarda çeşitli disiplinler tarafından insanın iyi olma hali, sorunlarla baş etme pratikleri, psikolojik yllmazlığın geliştirilmesi gibi alanlarda maneviyatın etkisi çalışılmaya başlanmıştır. Bunun sonucunda maneviyatın baş etme becerilerini geliştiren koruyucu bir psikolojik faktör olabileceği sonucuna varan ve maneviyatın etkilerini araştıran çok sayıda çalışma maneviyat ve iyi olma hali arasındaki ilişkiye yönelik ilgiyi arttırmıştır.

\section{Manevi İyilik Hali}

Manevi iyilik hali kavramı ilk kez 1975 yılında Yaşlanma Üzerine Atina Ulusal Dinlerarası Koalisyonu tarafından tanımlanmıştır. Buna göre manevi iyilik hali, kişinin manevi olarak değer verdiği Tanrı, toplum ve kendisi ile tutarlı ve dengeli bir bütünleşme içerisinde olmasıdır. ${ }^{8} \mathrm{Bu}$ tanımlama manevi iyiliğin dinî, sosyal ve psikolojik bileşenleri olduğunu ifade etmektedir. Aynı yıllarda manevi iyilik halinin tanımlanması ile ilgili araştırmalarda da bu tutum devam etmiştir. Örneğin manevi iyilik insanın varoluşundaki anlamı ve hedeflerini bulmaya yönelik istek, sorgulama,

\footnotetext{
${ }^{4}$ Yasemin Odabaș, "Engelli Çocuk Annelerine Verilen Manevi Bakım Desteğinin Manevi İyilik ve Umut Düzeylerini Arttırmaya Etkisinin Değerlendirilmesi" (Yayımlanmamış Yüksek Lisans Tezi, Zonguldak Bülent Ecevit Üniversitesi, Zonguldak, 2020), s.32.

${ }^{5}$ Craig Ellison, "Spiritual Well-Being: Conceptualization and Measurement," Journal of Psychology and Theology 11:4 (1983), ss.330-338.

${ }^{6}$ Öznur Özdoğan, "İnsana Manevi-Psikolojik Yaklaşım," Ankara Üniversitesi İlahiyat Fakültesi Dergisi 49:2 (2008), ss.77-102.

${ }^{7}$ Alvin Dueck, Indigenous Psychology of Spirituality: In My Beginning is My End (New York: Springer Nature, 2020), s.12.

${ }^{8}$ National Interfaith Coalition on Aging, Spiritual Wellbeing: A Definition (Athens: NICA, 1975), s.34.
} 
soyut şeyleri anlamaya çalışma, kendi içindeki ve dışındaki güçleri fark edebilme ve uyum sağlama durumu olarak tanımlanmıștır. ${ }^{9}$

Manevi iyilik hali, dikey ve yatay bileşenleri içeren bir kavram seti olarak ele alınmıștır. Dikey boyutta ilk olarak Tanrı ile ilgili olarak esenlik duygusuna atıfta bulunulmuştur.10 Yatay boyutta ise herhangi bir dinî hususa atıfta bulunmadan, bir yaşam amacı ve yaşam doyumu duygusuna vurgu yapılmıştır. Yatay boyut özellikle varoluşsal bir esenlik duygusuna sahip olmakla, kişinin neyi ve neden yapacağl, kim olduğu ve nereye ait olduğu ile ilişkili olarak değerlendirilmiştir. ${ }^{11} \mathrm{Bu}$ iki boyut da birbirini etkileyen ve birbirinden etkilenen, entegre olan iki süreç olarak bir arada kullanılmıştır. ${ }^{12}$ Bunun sonucunda ise manevi iyilik halinin bireye kimlik duygusu sağlayan bir süreci içerdiği anlaşılmıştır. Bu kapsamda manevi iyilik halinin kişinin kendisiyle, başkalarıyla, ilahi olanla ve doğayla olan ilişkileri olumlu duygu ve davranışlara dönüștüren bir yönünün olduğu ifade edilebilir. Bu bağlamda manevi iyilik hali insan zihninin, bilincinin ve bilinç dışının tamamını kapsayan "psişeden" ve insan bedeninin bütününü kapsayan "somadan" ayrı olarak mevcut değildir; bunları bütünleştirici bir güç sağlar. Fiziksel durum, duygular, düşünceler ve ilişkiler manevi iyilik halinden etkilenir ve onu etkiler.

\section{Manevi İyilik Halinin Değerlendirilmesine İlişkin Ölçme Araçları}

Manevi iyilik hali, Dünya Sağlık Örgütü tarafından sağlığın önemli bir bileşeni olarak kabul edildikten sonra literatürdeki çalışmalarda manevi iyilik halinin nasıl ölçüleceğine ilişkin bazı ölçüm araçlarının geliştirildiği görülmektedir. ${ }^{13} \mathrm{Bu}$ kapsamda geliştirilen ölçeklerin neler olduğu tarihsel süreç gözetilerek ortaya konulabilir.

Manevi iyilik hali ile ilgili geliştirilen ilk ölçek Ellison tarafından 1983 yılında ortaya konulan “Manevi İyi Oluş Ölçeği”dir. Manevi İyi Oluş Ölçeği,

\footnotetext{
9 Joseph Opatz, "Stevens Point: A Longstanding Program for Students at a Midwestern University," American Journal of Health Promotion 1:1 (1986), s.5.

10 Hatice Acar, "Manevi İyi Oluş ile Dindarlık Arasındaki İliş̧ki Üzerine Bir Değerlendirme," Cumhuriyet Üniversitesi Illahiyat Fakültesi Dergisi 18:2 (2014), ss.391-412.

11 Semra Altuntaş ve Sevde Düzgüner, "Duygusal Özgürleșme Tekniği (Eft) ile Destek Alan Kadınlarda Bireysel, Sosyal ve Manevi Değişim Üzerine Nitel Bir Araștırma," Ankara Üniversitesi Ilahiyat Fakültesi Dergisi 61:2 (2020), ss.453-492.

12 Raymond Paloutzian ve Craig Ellison, Developing A Measure of Spiritual Well-Being (New York: The American Psychological Association, 1979), s.31.

${ }_{13}$ World Health Organization, Spiritual Aspects of Health (South-East Asia: WHO Regional Office Press, 1998), s.38.
} 
dini ve varoluşsal iyi oluş halini değerlendirmektedir. ${ }^{14}$ Bu ölçeğin içerdiği maddelerin geliştirildiği bir diğer ölçek olan "Maneviyatı Değerlendirme Envanteri" ise yaşamın anlamı, amacı, aşkın ve içsel olma durumu ile varoluşsal iyilik halini değerlendirmektedir. ${ }^{15}$ Takip eden ylllarda manevi iyilik halinin bileșenlerinin neler olduğu ile ilgili çalışmalar gerçekleștirilmiştir. Yaşlanma Üzerine Ulusal Dinlerarası Koalisyonu tarafından, manevi iyilik halinin bileşenlerini bir çerçeve olarak kullanan bir ölçme aracı, Fisher tarafından 1998 yılında tasarlanmıştır. Bu ölçme aracından elde edilen bulgular manevi iyilik halinin insanların kendileriyle (kişisel), başkalarıyla (toplumsal), doğayla (çevresel) ve Tanrı'yla (ya da ilahi olarak atfedilen diğer alanlar) ilişkilerinde ne ölçüde uyum içinde yaşadıklarının incelenmesinin önemli olduğunu göstermektedir.

Buna göre kişisel alan; kişinin yaşamdaki anlam, amaç ve değerler açısından kendisiyle nasıl ilişki kurduğuyla ilgilenmektedir. Toplumsal alan; benlik ve diğerleri arasındaki kişiler arası ilişkilerin niteliği ve derinliğini ifade etmekte ve sevgi, adalet, umut ve insanlığa olan inancı içermektedir. Çevresel alan; huşu içinde olma, merak ve çevre ile birlik duygusu da dahil olmak üzere, fiziksel ve biyolojik dünya için özen ve bakım ile ilgilenmektedir. İlahi (aşkın) alan; benliğin, kozmik bir güç, aşkın gerçeklik veya Tanrı gibi insan düzeyinin ötesindeki bir şeyle veya birisiyle olan ilişkisi ile ilgilenmektedir ve gizemin kaynağına olan inancı içermektedir. ${ }^{16}$ 2000 'li yıllara gelindiğinde ise maneviyatın günlük yaşamdaki etkisi üzerine çalışmaların yapıldığı görülmektedir. Örneğin, 2002 yılında “Günlük Manevi Deneyimler Ölçeği” Underwood ve arkadaşları tarafından geliştirilmiş olup, dini tercihler açısından anlam ve değerlere varoluşsal yönlerden yaklaşmayı amaçlamaktadır.17 Bireylerin manevi yönelimlerini değerlendirmeye ilişkin "Manevi Yönelim Ölçeği" ise Kasapoğlu tarafından 2015 yllında geliştirilmiştir. ${ }^{18}$

\footnotetext{
${ }^{14}$ Craig Ellison, "Spiritual Well-Being: Conceptualization And Measurement," Journal of Psychology and Theology 11:4 (1983), ss.330-340.

${ }^{15}$ Judy Howden, "Development and Psychometric Characteristics of The Spirituality Assessment Scale" (Yayımlanmamış Doktora Tezi, Texas Woman's University, Texas, 1992), s.88

${ }^{16}$ John Fisher, "Spiritual Health: Its Nature, And Place in the School Curriculum" (Yayımlanmamış Doktora Tezi, Melbourne University, Victoria, 1998), s.18.

17 Lynn Underwood ve Jeanne Teresi, "The Daily Spiritual Experience Scale: Development, Theoretical Description, Reliability, Exploratory Factor Analysis, and Preliminary Construct Validity Using Health-Related Data," Annals of Behavioral Medicine 24:1 (2002), ss.22-33.

18 Figen Kasapoğlu, "Manevi Yönelim Ölçeği'nin Geliştirilmesi: Geçerlik ve Güvenirlik," İnönü Üniversitesi Eğitim Fakültesi Dergisi 16:3 (2015), s.51.
} 
2010'lu yıllara gelindiğinde ulusal literatürde manevi iyilik halinin değerlendirilmesine yönelik çeşitli ölçme araçlarının geliştirildiği görülmektedir. Örneğin, "Spiritüel İyilik Hali Ölçeği" yetişkinlerin manevi iyilik halini ölçmek amacıyla geliştirilmiş ve 29 maddeyi içerecek biçimde Ekşi ve Kardaş tarafından 2017 yılında oluşturulmuştur. ${ }^{19}$ Ölçeğin "bireyin dünya hayatının geçiciliğine inanması, inançların bireye yaşamında yol göstermesi, ilahi bir gücün varlığına inanma ve ondan güç almasını" içeren aşkınlık; "bireyin doğaya ve çevresindekilere saygıyla yaklaşmasını" içeren doğayla uyum ve "bireyin daha çok yaşamdaki olumsuzlukları üzerine durmakta ve hayattan zevk almama gibi durumlarını" içeren anomi alt boyutları bulunmaktadır. "Manevi İyilik Hali Ölçeği"nin (FACIT-Sp-12) Türkçe sürümü ise Ay ve arkadaşları tarafından 2019 yllında yapılmıştır. ${ }^{20}$ Gerçekleştirilen bu çalışmalar tinsel alanda iyilik halinin değerlendirilmesinde dikkat çeken bir alanın yeniden ön plana çıkmasını sağlamıştır.

Günümüzde bütüncül iyilik anlayışının yaygınlaşması ile beraber maneviyat ve manevi iyilik hali ile ilgili çalışmalar gerek dini bilimlerde gerekse felsefe, psikoloji ve sosyal hizmet gibi alanlarda gelişmeye ve dikkat çekmeye devam etmektedir. Bu noktada manevi iyilik halinin gerek nicel gerekse nitel yönlerden değerlendirilmesine gereksinim duyulabilmektedir. Manevi iyilik halini değerlendirdiğini ortaya koyan kabul edilebilir geçerlilik ve güvenilirlik gösteren bir dizi ölçme aracı bulunmaktadır. $\mathrm{Bu}$ ölçme araçları genellikle uluslararası literatürde karşımıza çıkmakta olup bu değerlendirmelerin çoğu en büyük dinî gruplardan biri olan Hıristiyanlara odaklanmaktadır. Buna karşılık Türkiye'de ilgili literatür incelendiğinde manevi konulara yönelik çalışmaların sınırlı olduğu görülmektedir. Manevi iyilik halini değerlendirmek için çeşitliliğin göz önüne alınması da önem taşımaktadır. Bu kapsamda Ingersoll tarafından 1995 yllında geliştirilen "Manevi İyilik Hali Envanteri" manevi iyiliği çok boyutlu olarak değerlendirmeyi sağlayan bir araç olma özelliğine sahiptir. Envanter, bireylerin manevi iyilik halini değerlendirmek amacıyla pek çok araştırmada kullanılmıştır. Bu araştırma da bu bilgiler ve açıklamalar ışığında, manevi iyilik halinin değerlendirilmesiyle ilgili alandaki eksikliğin

\footnotetext{
${ }^{19}$ Halil Ekşi ve Selami Kardaş, "Spiritual Well-Being: Scale Development and Validation," Spiritual Psychology and Counseling 2:3 (2017), s.88.

${ }^{20}$ Semra Ay ve diğerleri, "The Psychometric Properties of the Turkish Version of The Spiritual WellBeing Scale (FACIT-Sp-12) in Older Adults Living in Nursing Homes," Anatolian Journal of Psychiatry 19 (2019), ss.22-28.
} 
giderilmesi ihtiyacına karşılık gelmektedir. Bu çalışma ile manevi iyilik halinin birden çok bileşenini barındıran bir değerlendirme aracı geliştirilmeye çalışılmıştır. Ingersoll'un geliştirdiği "Manevi İyilik Hali Envanteri" bu alanda kullanılan diğer çalışmalarla kıyaslandığında bu envanterin diğerlerinden farklı özelliklere sahip olduğu görülmektedir. Bu envanter manevi iyiliği çok boyutlu olarak ele almayı amaçlayan pek çok bileșeni (kutsallık kavramı, anlam, bağlantılılık, an merkezcilik, gizem, ritüel, umut, bağışlayıcılık, bilgi ve öğrenme ve manevi özgürlük) içermektedir. Envanterin bu yönü ile diğer ölçme araçları yoluyla elde edilmesi olanaklı olmayan bütüncül bir değerlendirmenin yapılması olanaklı hale gelmiştir. Envanter, sahip olduğu bu geniş değerlendirme alanı sebebiyle uluslararası literatürde pek çok araştırma kapsamında kullanılmıştır. ${ }^{21} \mathrm{Bu}$ bağlamda ulusal literatürde manevi iyilik halinin değerlendirilmesini odağına alan çalışmalarda kullanılması amacıyla Ingersoll tarafından geliştirilen Manevi İyilik Hali Envanteri'nin Türkçeye uyarlama çalışması yapılmıştır.

\subsection{Manevi İyilik Hali Envanteri}

Manevi iyilik ile ilgili çalışmalarda sıklıkla kullanılan ölçme araçlarından Manevi İyilik Hali Envanteri (MİHE), danışanlarla yapılan uygulamalarda maneviyat ile ilişkili boyutlara dair inceleme yapmayı sağlayacak bir araç yaratmak amacıyla geliştirilmiştir.22 Ingersoll maneviyatı çok boyutlu bir kavram olarak ele almıştır. Buradan hareketle oluşturulan MïHE, ruhsal iyiliğin on boyutunu içermektedir. Bu boyutlar kutsallık kavramı, anlam, bağlantılılık, an-merkezcilik, gizem, ritüel, umut, bağışlayıcılık, bilgi ve öğrenme ile manevi özgürlük alanlarını içermektedir. ${ }^{23}$ Ingersoll envantere verilen yanıtlar karşısında katılımcıların kendilerini aşırı olumlu veya olumsuz göstermesi ile ilgili eğilimleri ele almak için "sahte iyilik" halini içeren bir alt boyutu daha envantere eklemiştir. ${ }^{21} \mathrm{Bu}$ doğrultuda envanterde yer alan alt alanlar Ingersoll tarafından aşağıdaki gibi tanımlanmıștır: ${ }^{21}$

\footnotetext{
${ }^{21}$ Elliot Ingersoll, "Spiritual Wellness in The Workplace," Giacalone and Carole Jurkiewicz (ed.), Handbook of Workplace Spirituality and Organizational Performance (London, Routledge, 2010) içinde, ss.232-242; Mazhar Iqbal Bhatti, Naila Batool, Muhammad Naveed R Riaz, "Relationship Between Spiritual Wellness and Quality of Life Among University Students," Pakistan Journal of Psychology 42:2 (2011), ss.55-64.

${ }_{22}$ Elliot Ingersoll, "Construction and initial Validation of The Spiritual Wellness Inventory" (Yayımlanmamıs Doktora Tezi, Kent State University, Ohio, 1995), s.12.

23 Chivonna Childs, "Exploratory Factor Analysis of The Spiritual Wellness Inventory" (Yayımlanmamıș Doktora Tezi, Cleveland State University, Ohio, 2014), s.28.
} 
Kutsallık kavramı: Kişinin tanrısallık kavramını ifade eder. İnsanların kutsalı tasavvur etme varyasyonlarını ele alır.

Anlam: Envanterde yer alan bu boyut kişinin hayatındaki amaç arayışına atıfta bulunur. Deneyimlerden anlam çıkarma yeteneği bireyin refahı için esas olarak değerlendirilmektedir.

Bağlantılılık: Kişinin kendisiyle olan içsel bağlantısının yanı sıra başkaları, çevresi ve inanç sistemi ile deneyimlenen bağlantı anlamina gelir.

Gizem: Kişinin hayatta beklenen veya beklenmedik zorluklarla nasıl başa çıktığını ifade eder.

Manevi Özgürlük: Bireyin kısıtlamalar veya korkular olmadan yaşama yeteneği ile ilgilidir. Kişinin kendini güvende hissederken hayattan zevk alma ve deneyimleme yeteneğinden bahseder, bu boyutta insanlar kendileri olmakta özgürdür.

Ritüel: $\mathrm{Bu}$ alt boyut kişinin yaşamını zenginleştiren ritüellere katılma durumu ve deneyimleriyle ilgilenir. $\mathrm{Bu}$ boyut, bireyin kendisiyle, başkalarıyla, çevresiyle ve inanç sistemiyle sağlıklı bir bağ kurmasıyla sonuçlanan kişisel ritüelleri ifade eder.

Bağışlayıcılık: Affetme, başkası tarafından bağışlanmanın yanı sıra başkalarını da bağışlama yeteneğini kapsar.

Umut: Geleceğe yönelik olumlu bir bakış açısını sürdürme durumunu ifade eder.

Bilgi ve öğrenme: $\mathrm{Bu}$ alt boyut kişinin kendisi ve başkaları hakkında daha fazla ve daha derin bilgi arama davranışlarına atıfta bulunur.

An-merkezcilik: Gerçek olanı (hakikati) deneyimlemek için mümkün olduğunca anda olmak ile ilgilidir.

Sahte iyilik: $\mathrm{Bu}$ alt boyut katılımcların verdikleri yanıtlarda kendilerini daha iyi gösterme eğilimlerini tespit etmek için sahte iyi yanıtları ele alan öğeler içermektedir.

\subsubsection{Puanlama}

MiHE, manevi iyilik halini incelemek amaciyla 55 maddeden oluşmaktadır. Maddeler (1) "kesinlikle katılıyorum" ile (8) "kesinlikle katılmıyorum" arasında değişen Likert tipi bir ölçek biçiminde geliştirilmiştir. Ölçeğin tek sayıda bulunan soruları ters kodlanmaktadır. Ölçeğin puanlanmasında her bir alt boyuta ilişkin puanlar toplanmaktadır. 
Ölçeğin alt boyutları ise şu soruları içermektedir: kutsallık kavramı $(1,12$, $23,34,45)$, anlam $(2,13,24,35,46)$, bağlantılılık $(3,14,25,36,47)$, an merkezcilik $(4,15,26,37,48)$, gizem $(5,16,27,38,49)$, ritüel $(6,17,28,39$, $50)$, umut $(7,18,29,40,51)$, bağışlayıcılık $(8,19,30,41,52)$, bilgi ve öğrenme $(9,20,31,42,53)$, manevi özgürlük $(11,22,33,44,55)$ ve sahte iyilik $(10,21,32,43,54)$. Ölçekte toplam skor bulunmamakta olup her bir alt boyuttan alınan puan aşağıda yer alan profile işlenmektedir:

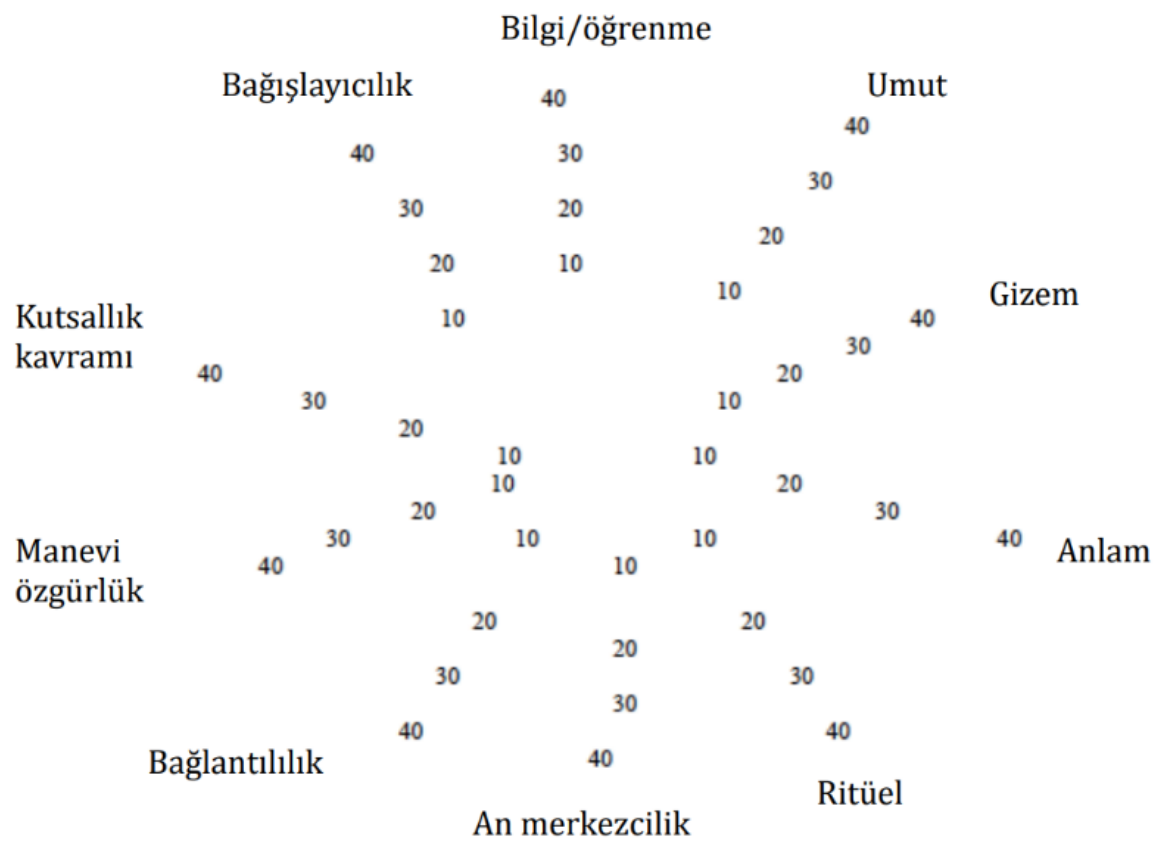

Şekil 1: MìHE Puanlarının Profile İșlenmesi

\section{Yöntem}

\subsection{Katılımcilar}

Atatürk Üniversitesinde öğrenci olan 513 kişi (\%64'ü kadındır, yaş

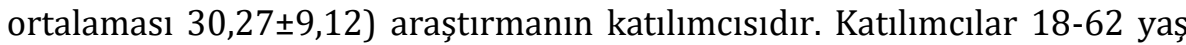
arasındadır. Katılımcların \%60'ı bekar iken \%76'sı orta düzey sosyoekonomik seviyede bulunmaktadır. \%71,7'si ailesi ile beraber yaşamaktadır. \%32,9'u 1. sınıf, \%43,3'ü 2. sınıf, \%9,7'si 3. sınıf ve \%14'ü 4. sinıf öğrencisidir (Tablo 1). 


\begin{tabular}{|l|l|l|}
\hline Cinsiyet & Sayı & Yüzde (\%) \\
\hline Kadın & 328 & 64 \\
\hline Erkek & 185 & 36 \\
\hline Medeni Durum & & \\
\hline Evli & 206 & 40 \\
\hline Bekar & 307 & 60 \\
\hline Algılanan Sosyo-ekonomik Düzey & & \\
\hline Alt & 104 & 20,3 \\
\hline Orta & 390 & 76 \\
\hline Üst & 19 & 3,7 \\
\hline Kiminle Yaşıyor & & \\
\hline Yalnız yaşıyor & 40 & 7,8 \\
\hline Çekirdek ailesi ile beraber yaşıor & 368 & 71,7 \\
\hline Geniş ailesi ile beraber yaşıor & 49 & 9,6 \\
\hline Arkadaşları ile beraber yaşıyor & 8 & 1,6 \\
\hline Diğer & 48 & 9,4 \\
\hline Devam Ettiği Sınıf & & \\
\hline 1. sinıf & 169 & 32,9 \\
\hline 2. sinıf & 222 & 43,3 \\
\hline 3. sinıf & 50 & 9,7 \\
\hline 4. sinıf & 72 & 14,1 \\
\hline Yaş (Minimum; Maksimum; Ortalama + Standart sapma) & $(18 ; 62 ; 30,27 \pm 9,12)$ \\
\hline & & \\
\hline
\end{tabular}

Tablo 1: Katılımcıların Demografik Bilgileri

\section{2. Ölçümler}

Araştırmaya katılanlara ait temel bilgilerin elde edilebilmesi amacı ile demografik bilgi formu kullanılmıştır. Ingersoll tarafından geliştirilen ve doğrulanan 55 madde ve on bir alt boyuttan oluşan MïHE, Türkçeye çevrilmiştir. 8'li Likert tipinde olan kaynak ölçekte tek sayı ile belirtilen maddeler ters kodlanmaktadır. Kaynak ölçeğin geliştirildiği çalışmada, ikinci düzey doğrulayıcı faktör analizinde iç tutarlılık katsayısının 0,88 olarak bulunduğu belirtilmektedir. 


\subsection{Verilerin Toplanması}

Araştırmaya dair veriler, araştırmacılar tarafından oluşturulan çevrimiçi formlar aracılığıyla toplanmıştır. Sosyo-demografik bilgi formu ve kaynak, ölçeğin Türkçe formu çevrimiçi formlara uyarlandıktan sonra formun internet bağlantısı katılımcılar ile paylaşılmıştır. Veriler 17/04/2021 ile 10/06/2021 tarihleri arasında toplanmıştır.

\subsection{Verilerin Analizi}

Verilerin analizi Lisrel 8.80 ve SPSS 25 ile gerçekleștirilmiştir. Veriler analiz edilmeden önce normal dağılım testi yapılmıştır. Toplanan verilerin basıklık ve çarpıklık değerlerinin -1 ile +1 arasında olduğu görülmektedir. Buna göre verilerin normal dağıldığı varsayılmıştır. MïHE'nin orijinal yapısının doğrulanıp doğrulanmadığının belirlenmesi amacıyla doğrulayıcı faktör analizi (DFA) yapılmıştır.

\subsection{Hedef Dile Çeviri}

Dünya Sağlık Örgütü'ne göre kaynak dilde geliştirilen ve hedef dile ve kültüre uyarlanan ölçek, uyarlanan kültürde de uygulama sürecinde de benzer biçimde çalışmalıdır. ${ }^{24}$ Uyarlamanın odak noktası, dilsel eşdeğerlikten ziyade kültürler arası ve kavramsaldır. Bu hedefe ulaşmak için köklü bir yöntem, ileri çeviriler ve geri çeviriler kullanılmalıdır. Bu yönergeler ışığında aşağıdaki adımları içeren çeviriye ilişkin bilgiler şu şekildedir:

\section{Adım: İleri Çeviri}

Ingersoll tarafından geliştirilen MİHE çok iyi düzeyde İngilizce bilen ve ilgili alanda çalışmalar gerçekleştirmiş olan iki akademisyen ve Filoloji mezunu olan bir meslek elemanı tarafından ayrı ayrı Türkçeye çevrilmiştir. $\mathrm{Bu}$ sayede elde edilen üç ayrı form bir sonraki basamak olan uzman panelinde karşılaştırılmıştır.

\section{Adım: Uzman Paneli}

$\mathrm{Bu}$ aşamada temel amaç, gerçekleştirilen çevirilerde yer alan yetersiz ve eksik ifadelerin ve kavramların tespit edilmesi, birbirleri ile karşılaştırılması ve dilsel söylemlerdeki tutarsızlıkların revizyonlarının gerçekleştirilmesidir. Çalışmanın bu aşamasında ilgili alanda çalışan iki akademisyen tarafından uzman paneli oluşturulmuştur. Uzman paneli

\footnotetext{
${ }^{24}$ Dünya Sağlık Örgütü, "Process of Translation and Adaptation of Instruments," https://www.who.int/substance_abuse/research_tools/translation/en/ (28.06.2021)
} 
çevrimiçi yollarla gerçekleştirilmiş ve ölçekte yer alan her bir maddenin çevirisi tek tek ele alınmıştır. Bu çalışmanın sonucunda kaynak ölçeğin tam olarak Türkçeye çevrilmiş formu oluşturulmuştur.

\section{Adım: Geri Çeviri}

$\mathrm{Bu}$ aşamada uzman paneli sürecinde yapılan çalışmanın sonucunda elde edilen kaynak ölçekten Türkçeye çevrilen form yeniden kaynak dil olan İngilizceye profesyonel tercümanlar tarafından çevrilmiştir. Kaynak ölçek ile geri çeviri sonrasında elde edilen formda yer alan maddeler tek tek karşılaştırılarak olası anlam farklılıkları değerlendirilmiştir.

4. Adım: Ön-Test Aşaması

Çalışmanın bu aşamasının temel amacı elde edilen formun hedeflenen kültürde ön-testinin gerçekleștirilmesidir. $\mathrm{Bu}$ amaç doğrultusunda elde edilen form, 87 kişiden oluşan öğrenci grubuna uygulanarak DFA yapılmıştır. Ayrıca 24 öğrenciden oluşturulan bir gruptan forma ilişkin yazılı görüş alınmıştır. Gerçekleștirilen bu çalışmalar sonucunda anlaşılmadığı düşünülen sekiz madde üzerinde ufak çaplı değişiklikler yapılmış ve böylece formun daha iyi anlaşılması hedeflenmiştir.

\section{Adım: Son Sürümün Oluşturulması ve Dokümantasyon Süreci}

Çalışmanın bu son aşamasında gerekli adımlar izlendikten sonra formun son sürümü oluşturulmuştur. Formun son sürümü geçerlik ve güvenirliğe ilişkin çeşitli analizlerin yapılabilmesi amacıyla internet kanalıyla ve Google Formlar aracılığıyla katılımcılara ulaştırılarak veri toplama aşamasına geçilmiştir.

\section{6. Çalışmanın Etik Yönü}

Çalışmanın gerçekleştirilmesinde öncelikle MïHE'yi geliştiren Ingersoll ile iletişime geçilmiş, çalışmanın amacı ifade edildikten sonra envanterin Türkçeye uyarlanabilmesi için yazılı izin alınmıştır. Ardından Atatürk Üniversitesi Sosyal ve Beşeri Bilimler Etik Kuruluna başvuru yapılarak gerekli izinler alınmıştır (Etik Kurul Toplantı Tarihi: 17.05.2021, Toplantı Karar no:107).

\section{Bulgular ve Değerlendirme}

Analiz sonucunda belirlenen model Şekil 2'de gösterilmiştir. 


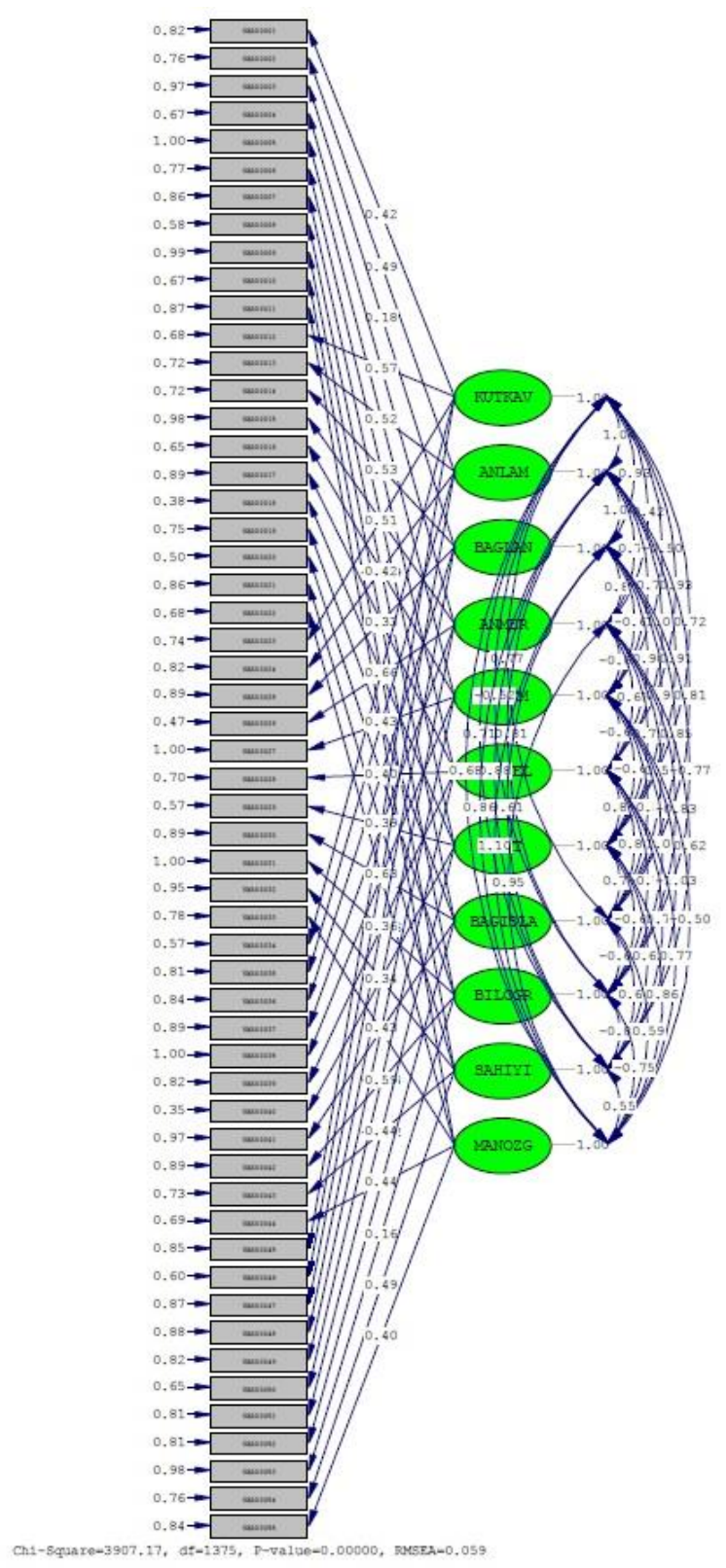

Şekil 2: MİHE Doğrulayıcı Faktör Analizi Modeli (Standartlaştırılmış Değerler).

Kısaltmalar: KUTKAV: Kutsallık Kavramı, ANLAM: Anlam, BAGLAN: Bağlantılılık, ANMER: An merkezcilik, GIZEM: Gizem, RITUEL: Ritüel, UMUT: Umut, BAGIS: Bağışlayıcılık, BILOGR: Bilgi ve Öğrenme, SAHIYI: Sahte İyilik, MANOZG: Manevi Özgürlük 
Şekil 2 incelendiğinde, doğrulayıcı faktör analizi (DFA) sonucunda belirlenen ki-kare ve serbestlik derecesi değerlerinin $\chi^{2}=3907,17$, ( $\mathrm{sd}=1375, \quad \mathrm{p}<.01)$ olduğu ve $\chi^{2} / \mathrm{sd}=2,84$ oranının elde edildiği görülmektedir. Seçilen örneklemden elde edilen bu oranın 3'ün altında çıkması mükemmel uyuma işaret etmektedir. ${ }^{25} \mathrm{Bu}$ araştırmada DFA sonucunda belirlenen model ile veri arasındaki uyumun mükemmel uyuma karşıllk geldiği söylenebilir. Diğer belirlenen uyum değerleri Tablo 2'de özetlenmiştir.

\begin{tabular}{ccccccccccc}
\hline$\chi^{2}$ & sd & $\chi^{2} / \mathbf{s d}$ & RMSEA & AGFI & SRMR & RMR & NNFI & CFI & NFI & IFI \\
\hline 3907,17 & 1375 & 2,84 & 0,059 & 0,83 & 0,005 & 0,08 & 0,98 & 0,98 & 0,95 & 0,98 \\
\hline
\end{tabular}

Tablo 2: DFA Sonucunda Belirlenen Uyum Değerleri

DFA'da en yaygın kullanılan uyum indekslerinden birisinin RMSEA (Root Mean Square Error of Approximation) olduğu söylenebilir. DFA analizinde RMSEA indeksinin 0,05 ve daha küçük bir değer olması modelveri uyumunun bir göstergesidir; ancak bu değerin 0,08'e kadar da kabul edilebileceği belirtilmektedir. DFA'da AGFI (Adjusted Goodness of Fit Index) değerinin 0,80'den yüksek, RMR (Root Mean Square Residual) değerinin "0,10" dan ve SRMR (Standardized RMR) değerinin "0,08" den daha düşük olmasının, modelin gerçek verilerle uyumu için kabul edilebilir olduğu söylenebilir. DFA'da NNFI (Non-Normed Fit Index), CFI (Comparative Fit Index), NFI (Normed Fit Index) ve IFI (Incremental Fit Index) değerlerinin 0,95 ve üzerinde olması model veri uyumunun "mükemmel uyuma" karşılık geldiğinin göstergesidir. ${ }^{26}$

\section{Sonuç ve Öneriler}

DFA'nın temel amacı önceden tanımlanan bir modelin, elde edilen veriler ile uyum düzeyini belirlemektir. ${ }^{27} \mathrm{Bu}$ bağlamda doğrulayıcı faktör analizi sonucunda belirlenen uyum indekslerine göre MIHHE'nin 11 boyutlu yapısının doğrulandığı söylenebilir.

\footnotetext{
${ }^{25}$ Karl Jöreskog ve Dag Sörbom, Lisrel 8: Structural Equation Modeling with the Simplis Command Language (Hillsdale: Erlbaum Associates Publishers, 1993), s.102; Nebi Sümer, "Yapısal Eșitlik Modelleri: Temel Kavramlar ve Örnek Uygulamalar," Türk Psikoloji Yazıları 3:6 (2000), ss.49-73; Rex Kline, Principles and Practice of Structural Equation Modeling (New York: The Guilford Press, 2005), s.21.

${ }^{26}$ Armando Luis Vieira, Interactive LISREL in Practice (London: Springer, 2011), s.39.

${ }^{27}$ Kadir Sümbüloğlu ve Beyza Akdağ, İleri Biyoistatistiksel Yöntemler (Ankara: Hatipoğlu Yayınları, 2009), s.23.
} 
Sonuç olarak MïHE'yi oluşturan maddelerin istendik özelliklerde olması, envanterin Türkiye'de insanların manevi iyilik durumunu belirlemede kullanılabileceğini, ayrıca envanterin bu özelliklerinin orijinal haliyle benzerlik göstermesi, Türkçe formunun Türkiye'de kullanılabileceğini göstermektedir. Bu bağlamda MïHE, bireylerin yanı sıra çeşitli nüfus grupları için bir değerlendirme aracı olarak kullanılabilir. Ayrıca envanterin, manevi iyilik halinin güçlendirilmesi amacıyla gerçekleştirilebilecek mesleki uygulamaların (bireyle çalışma, grupla çalışma gibi) etkililiğini değerlendirebilmek amacıyla da kullanılabileceği düşünülmektedir.

Çalışmanın bazı kısıtlılıkları bulunmaktadır. Çalışma tarama modelinde kesitsel bir saha çalışması yürütülmüş; 513 kişinin katılımıyla ve tek bir örneklem grubu ile gerçekleştirilmiştir. Çalışmanın daha fazla katılımcıyı içerecek biçimde ve farklı örneklem grupları ile yeniden gerçekleştirilmesinin ölçeğin geçerliliğini ve güvenirliğini artıracă̆ düşünülmektedir.

Çıkar Çatışması / Conflict of Interest:

Finansal Destek / Grant Support:

Etik Kurul Onayı / Ethics Committee Approval: Bu araştırma, Atatürk Üniversitesi Sosyal ve Beșeri Bilimler Etik Kurulu onayı ile yapılmıștır. Tarih: 17.05.2021, Karar no:107 / This research is conducted with the permission of the Humanities and Social Sciences Research Ethics Committee of Atatürk University, decree no: 107, 17.05.2021.

Yazar Katkıları / Author Contributions: $\quad$ Veli Duyan \%40, Cengiz Kılıç \%30, Merve Deniz Pak Güre \%30

\section{KAYNAKÇA}

Acar, Hatice. "Manevi İyi Oluş ile Dindarlık Arasındaki İlişki Üzerine Bir Değerlendirme," Cumhuriyet Üniversitesi İlahiyat Fakültesi Dergisi 18:2 (2014), ss.391-412.

Altuntaş, Semra ve Sevde Düzgüner. "Duygusal Özgürleşme Tekniği (EFT) ile Destek Alan Kadınlarda Bireysel, Sosyal ve Manevi Değișim Üzerine Nitel Bir Araştırma," Ankara Üniversitesi İlahiyat Fakültesi Dergisi 61:2 (2020), ss.453-492. 
Arslan, Hediye ve Şener Dilek Konuk. "Stigma, Spiritüalite ve Konfor Kavramlarının Meleis'in Kavram Geliştirme Sürecine Göre İrdelenmesi," Maltepe Üniversitesi Hemşirelik Bilim ve Sanatı Dergisi 2:1 (2009), ss.51-58.

Ay, Semra ve diğerleri. "The Psychometric Properties of the Turkish Version of the Spiritual Well-Being Scale (FACIT-Sp-12) in Older Adults Living in Nursing Homes," Anatolian Journal of Psychiatry 19 (2019), ss.22-28.

Bhatti, Mazhar Iqbal, Naila Batool, Muhammad Naveed R Riaz. "Relationship Between Spiritual Wellness and Quality of Life Among University Students," Pakistan Journal of Psychology 42:2 (2011), ss.55-64.

Childs, Chivonna. "Exploratory Factor Analysis of the Spiritual Wellness Inventory," Yayımlanmamış Doktora Tezi, Cleveland State University, Ohio, 2014.

Dueck, Alvin. Indigenous Psychology of Spirituality: In My Beginning is My End. New York: Springer Nature, 2020.

Dünya Sağllk Örgütü. "Process of Translation and Adaptation of Instruments." https://www.who.int/substance_abuse/research_tools/translation/en/ (28.06.2021).

Ekşi, Halil ve Selami Kardaş. "Spiritual Well-being: Scale Development and Validation," Spiritual Psychology and Counseling 2:3 (2017), ss.73-88.

Ellison, Craig. "Spiritual Well-being: Conceptualization and Measurement," Journal of Psychology and Theology 11:4 (1983), ss.330-338.

Fisher, John. "Spiritual Health: Its Nature, and Place in the School Curriculum," Yayımlanmamıș Doktora Tezi, Melbourne University, Victoria, 1998.

Howden, Judy. "Development and Psychometric Characteristics of the Spirituality Assessment Scale," Yayımlanmamış Doktora Tezi, Texas Woman's University, Texas, 1992.

Ingersoll, Elliot. "Construction and Initial Validation of the Spiritual Wellness Inventory," Yayımlanmamış Doktora Tezi, Kent State University, Ohio, 1995.

Ingersoll, Elliot. "Spiritual Wellness in the Workplace," Giacalone ve Carole Jurkiewicz (ed.), Handbook of Workplace Spirituality and Organizational Performance (London: Routledge, 2010) içinde, ss.232-242.

Jöreskog, Karl ve Dag Sörbom. Lisrel 8: Structural Equation Modeling with the Simplis Command Language. Hillsdale: Erlbaum Associates Publishers, 1993.

Kasapoğlu, Figen. "Manevi Yönelim Ölçeği'nin Geliştirilmesi: Geçerlik ve Güvenirlik," İnönü Üniversitesi Eğitim Fakültesi Dergisi 16:3 (2015), ss.51-68.

Kline, Rex. Principles and Practice of Structural Equation Modeling. New York: The Guilford Press, 2005.

National Interfaith Coalition on Aging, Spiritual Wellbeing: A Definition. Athens: NICA, 1975.

Odabaş, Yasemin. "Engelli Çocuk Annelerine Verilen Manevi Bakım Desteğinin Manevi İyilik ve Umut Düzeylerini Arttırmaya Etkisinin Değerlendirilmesi," Yayımlanmamış Yüksek Lisans Tezi, Zonguldak Bülent Ecevit Üniversitesi, Zonguldak, 2020. 
Opatz, Joseph. "Stevens Point: a Longstanding Program for Students at a Midwestern University," American Journal of Health Promotion 1:1 (1986), ss.60-67.

Oxford Dictionary, "Definition of Spirituality."

https://www.lexico.com/definition/spirituality (28.06.2021)

Özdoğan, Öznur. "İnsana Manevi-Psikolojik Yaklaşım,” Ankara Üniversitesi İlahiyat Fakültesi Dergisi 49:2 (2008), ss.77-102.

Paloutzian, Raymond ve Ellison Craig. Developing a Measure of Spiritual Well-Being. New York: The American Psychological Association, 1979.

Sheldrake, Philip. A Brief History of Spirituality. London: John Wiley \& Son, 2009.

Sümbüloğlu, Kadir ve Beyza Akdağ. İleri Biyoistatistiksel Yöntemler. Ankara: Hatipoğlu Yayınları, 2009.

Sümer, Nebi. "Yapısal Eșitlik Modelleri: Temel Kavramlar ve Örnek Uygulamalar," Türk Psikoloji Yazıları 3:6 (2000), ss.49-73.

Underwood, Lynn ve Jeanne Teresi. "The Daily Spiritual Experience Scale: Development, Theoretical Description, Reliability, Exploratory Factor Analysis, and Preliminary Construct Validity Using Health-Related Data," Annals of Behavioral Medicine 24:1 (2002), ss.22-33.

Vieira, Armando Luis. Interctive LISREL in Practice. London: Springer, 2011.

World Health Organization. Spiritual Aspects of Health. South-East Asia: WHO Regional Office Press, 1998.

\section{EK-1: Manevi İyilik Hali Ölçeği}

Elliott Ingersoll, Ph.D., PCC

Lütfen aşağıdaki maddelere, her bir maddeye ne kadar katılıp katılmadığınızı gösteren ölçekten bir sayı seçerek cevap veriniz. Her öğe numarasının yanındaki boşlukta seçtiğiniz numarayı işaretleyiniz.

Kesinlikle

Katılmiyorum

Kesinlikle Katılıyorum

1 2 3 4 5 6 7 8

1. Hayatımda Tanrı'nın varlığını hiç deneyimlemiyorum.

2. Hayatın anlamı, barışık olduğum bir meseledir.

3. Diğer insanlar için asla merhamet hissetmem.

4. Genellikle her anın tadını çıkarırım.

5. Hayat söz konusu olduğunda asla hușu içinde olmam.

6. Hayata bağlandığımı hissetmeme yardımcı olması için yaptığım şeyler var.

7. Umudu kaybetmek için geçerli sebepler vardır.

8. Tanrı'nın beni affetmesini istediğim gibi ben de diğer insanları affetmem gerektiğini hissederim.

9. İnançlarıma yönelik sorgulamaların birçoğunu reddederim.

10. Hayatta tüm insanların bir rolü olduğuna inanıyorum.

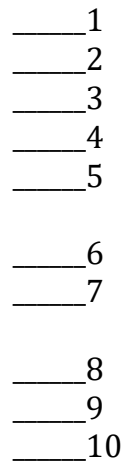


11. Dünyada kendimi güvende hissetmiyorum.

12. Maneviyatım diğer insanlarla bağlantı içinde olmamı arttırır.

13. Hayatımın anlamlı olduğunu asla deneyimlemiyorum.

14. Kendimi benim için önemli olan ve hayatımı büyük ölçüde etkileyen sağlıklı bir topluluğun parçası gibi hissediyorum.

15. Fiziksel hislere dikkatimi vermekten hoşlanmiyorum.

16. Hayat, olgunlaşma ve olumlu yönde dönüşümle ilgilidir.

17. Tanrı'nın varlığını hissetmem için ne yapmam gerektiğini bilmiyorum.

18. Her şey umutsuz görünse bile, işlerin daha iyiye gidebileceğine dair inancım var.

19. Diğer insanları affetmemin gerçekten bana bir yararı olmaz.

20. Yaşam şeklim, gerçekten kim olduğum hakkında bana büyük bir bilgi sağliyor.

21. İșleri olabildiğince doğru yapma konusunda direten ve sert kuralları olan bir insanımdır.

22. Hoşça geçirdiğim anları her gün deneyimlerim.

23. Tanrı'nın varlığına dair güçlü bir hissi içimde asla deneyimlemem.

24. Hayat deneyimlerimin anlamı hakkında her zaman derinlemesine düşünürüm.

25. Kendimi bir gruba aitmiş gibi hissetmiyorum.

26. Yaşadığım her bir anı genellikle tam anlamıyla hissederim.

27. Manevi inançlarımı sorgulamaktan korkuyorum.

28. Hayat benim için kutsaldır.

29. Hayatımın bir noktada yoluna gireceğine inancım çok az.

30. Hayatımdaki insanlar çoğunlukla bana karşı şefkatli ve merhametlidir.

31. Hayatımda karşılaştığım meseleleri irdelemem.

32. Zaman zaman zorlansam da kendi kendime acımayı engelleyebilirim.

33. Kendimi hayatın neyle ilgili olması gerektiği konusundaki tasvirlerin baskısı altında hissediyorum.

35. Hayatımdaki deneyimlerimden pek anlam çıkartmam.

36. Bisikletle veya yaya olarak bir yerden bir yere giderken genellikle doğadaki şeyleri fark ederim.

37. Bir sonraki işe geçmeden önce, başarıyla tamamladığım o işin hazzını yaşamam.

38. Belirsizlik ve muğlaklık, hayatın yararlı parçalarındandır.

39. Büyüdükçe yeni manevi ritüeller geliștirmedim.

40. Her an, umuda dair bir potansiyel vadeder.

41. Geçmiş yaralarıma dair dargınlıklarım var.

42. Kendim hakkında daha çok şey öğrendikçe daha fazlasını vermem gerekir.

43. Zorba tipler yerine kibar insanlarla birlikte olmayı tercih ederim.

44. Kendimi bir șeylere güçlü bir șekilde adama konusunda özgür 
hissederim.

45. Tanrı'ya olan inancım, doğayla temas halinde olmamı azaltır.

46. Maneviyatım benim için çok önemlidir.

47. Manevi olarak değer verdiğim insanların hayattan keyif almama yardımcı olmadığını hissederim.

48. Gelecekte olacakları düşündüğümde gerilmiyorum.

49. İşlerin tamamen kontrolümde olması benim için önemlidir.

50. Hayatıma maneviyatı katmama yardımcı olan ritüellerim var.

51. Kötüyken daha iyiye giden yaşantılarım olmadı.

52. Bir insanı yapabileceği herhangi bir şey için affedebilirim.

53. Bilgiye değer vermem için inançlarımla çatışmaması gerekir.

54. Konuşmadan önce görüşlerimin doğru olduğundan emin olana kadar beklerim.

55. Belli bir toplumsal imaja uygun yaşamak için büyük bir baskı hissederim. 
